\title{
Journal of Molecular and Genetic Medicine
}

\section{Phylogenetic Relationships of Sudanese Gazella dorcas Based on Mitochondrial Cytochrome-B Gene Sequences}

\author{
Salih RRM*, Imad-Eldain ETA and Abd-EIrahim EK \\ Department of Clinical Medicine, Faculty of Veterinary Medicine, University of Khartoum, Shambat, Bahry, Khartoum, Sudan
}

\begin{abstract}
Dorcas gazelles are critically endangered mammals on the Arabian World. Past conservation efforts have been plagued by confusion about the phylogenetic relationship among various 'phenotypically discernable' populations, and even the question of species boundaries was far from being certain. This lack of knowledge has had a direct impact on conservation measures. Here, we provide a phylogenetic framework, based on the analysis of mtDNA sequences. We applied molecular methods to document for the first-time patterns of genetic diversity and population structure of Gazella dorcas in Bahry and East of the Nile (Sudan) using 421 bp fragment of mitochondrial DNA in seventeen populations.
\end{abstract}

Keywords: Mitochondrial DNA; Cytochrome-b gene; DNA extraction

\section{Introduction}

The Dorcas gazelle (Gazella dorcas), which was once common throughout peri-Saharan North Africa, is no exception in this regard. Dorcas gazelles are thought to exist in a wide variety of habitats, from Sahelan savannahs to semi-arid gravel and sand deserts, while avoiding hyper arid areas and the upper elevations of the central-Saharan massifs [1-11]. Conservation efforts for Dorcas gazelles in different countries include the prohibition of hunting and establishment of protected areas. Most habitats across the species' natural range have not been degraded through over exploitation, so reintroduction programs remain a feasible option given that poaching is prevented. Various breeding centers have started actions to preserve Dorcas gazelles. Several subspecies of Dorcas gazelles were described on the basis of phenotypic variation, such as fur coloration, horn shape and length, and other morph metric measures, but genetic differentiation is generally not well documented, and the presumed taxa seem to show no obvious ecological differences congruent with the proposed taxonomic classification [12-16].

Mitochondrial DNA (mtDNA) is a good target for phylogenic reconstruction at several taxonomic levels. Phylogenic approaches normally use sequences from a single gene such as mitochondrial cytochrome- b gene, which is utilized for species and family level analysis as well as for resolution of taxonomic controversies. The increase in mutation rate of mtDNA is 5-10 times relative to a single copy nuclear gene which resulted in an accumulation of base substitutions over a long period of time. The ordering of mitochondrial genes often remains unchanged over long periods of evolutionary time [17-21].

No thorough phylogenetic or phylogeographic analyses focusing on Gazella dorcas have been conducted until now [19]. Mitochondrial DNA is suitable for phylogenic applications due to its very low recombination level and its abundance in small size compared with genomic DNA make [8]. In authenticating food products, a number of mtDNA genes are used as target for detecting or isolating different animal species. Cytochrome- b (Cyt-b) gene region is one of the conserved regions used as a molecular marker for this purpose [18]. Our present study was designed to fill this gap of knowledge.

The objective of this study to detect the phylogeny and phylography of Gazella dorcas by use of mcyt- b and increase the knowledge for wildlife field as one of the most important issues needs to be further research on it.

\section{Materials and Methods}

Whole blood in EDTA were collected from 17 Gazella dorcas from Hilat Kuku Zoo, Elkadaru's farm and Mozamel Elkurdi's farm in East of the Nile, Khartoum State. The origins of these animals are Dongola, River Nile- Northern Sudan and Butana- Central Sudan. Other blood samples were collected in EDTA from Shambat- Bahry from sheep, goats, cows, camels, donkeys, horses and pigs. The blood samples were used for DNA extraction by using commercial kit (QIAamp blood kit- QIAGEN Inc Chatsworth, CA, USA). Other samples were also taken from a slaughtered gazelle from heart, lung, liver, kidney, spleen, tongue, muscles of scapula, intestine, rumen, reticulum, omasum and lymph nodes. The size of PCR product was $421 \mathrm{bp}$. For specificity of PCR, DNA extracted from (dorcas gazelles, cows, sheep, goats, camels, pigs, horses and donkeys) was used with GZ1 and GZ2 primers.

\section{Selection of the primers for PCR}

For detecting the mitochondrial cytochrome-b gene for gazelle we designed the primers by use bioedit software with [accession number JN410257.1 of Gazella dorcas isolate from west 7 cytochrome- b (cytb) gene, complete cds; mitochondrial Tunisia from GenBank]. The left primers included bases of the positive sense strand of the positive sense strand 5: CCT AGT TCT CAC ACT CCT AGT T. The right primers include bases of the complementary strand 5: GAG ACT ATT TTC AAT GGT ACT. The PCR product $421 \mathrm{bp}$ and the primers were synthesized by World Meridian 10F, Gasan-dong, Geumcheon-gu, Seoul, 153-781 Korea.

\section{Extraction of DNA from blood samples}

For extraction of the DNA from blood samples we used commercial

*Corresponding author: Dr. Reem Rabie Mohammed Salih, Head of the Department of Clinical Medicine, Faculty of Veterinary Medicine, University of Khartoum, Shambat, Bahry, Khartoum, Sudan, Tel: 00249911388234; E-mail: reemat7@yahoo.com

Received September 14, 2018; Accepted November 10, 2018; Published November 14, 2018

Citation: Salih RRM, Imad-Eldain ETA, Abd-Elrahim EK (2018) Phylogenetic Relationships of Sudanese Gazella dorcas Based on Mitochondrial Cytochrome-B Gene Sequences. J Mol Genet Med 12: 379 doi:10.4172/1747-0862.1000379

Copyright: $\odot 2018$ Salih RRM, et al. This is an open-access article distributed under the terms of the Creative Commons Attribution License, which permits unrestricted use, distribution, and reproduction in any medium, provided the original author and source are credited 
kit (QIAamp blood kit- QIAGEN Inc Chatsworth, CA, USA) according to the manufacturer's instructions. Briefly, $200 \mu \mathrm{l}$ from the Lysing buffer (L.A) put in sterile epindorf tube, then added $200 \mu$ from the blood sample and added $10 \mu$ from lyses enhancer, vortexed the tubes then incubated in water bath at $70^{\circ} \mathrm{C}$ for 10 minutes. Add 200 $\mu \mathrm{l}$ absolute alcohol, vortexed and incubated in water bath at $70^{\circ} \mathrm{C}$ for 2 minutes. Transferred all contents from the epindorf tubes and put to QIA spin column. Spin at $8000 \mathrm{rpm}$ for 2 minutes and discarded the deposite. Washed with $500 \mu \mathrm{l}$ buffer one, vortexed and spin at 8000 rpm for 2 minutes. Changed the QIAamp column and washed with 500 $\mu \mathrm{l}$ buffer two, vortexed and spin at $12000 \mathrm{rpm}$ for 3 minutes. Discarded the deposit and put the QIAamp column in epindorf tube and add 200 $\mu \mathrm{l}$ from elution buffer and left for 1 minute. Put in the spin for 8000 $\mathrm{rpm}$ for 2 minutes then discard the column and saved the epindorf tube at freezing.

\section{Tissues preparation}

One dorcas gazelle slaughtered and took small part from different organs like: Tongue, lung, heart, liver, kidney, spleen, muscles, lymph node, rumen, reticulum, omasum, intestine). The tissues were prepared from different organs by chopping to small pieces finally to form homogenous extract by scalpel, put every tissue in separate epindorf tube, then add $300 \mu \mathrm{l}$ of distilled water (D.W) and voertexed hardly, put the tubes in deep freezing for 10 minutes, thawing and vortexed. Repeated these steps 3 times, then centrifuged all samples at $300 \mathrm{rpm}$ for 1 minute. Aspirated $200 \mu \mathrm{l}$ from supernatant for DNA extraction.

\section{Cooked meat preparation}

About 2 gm of scapular muscles was poiled for 5 minutes, chopped finely to form homogenous extract, the whole volume was moved to an epindorf tube and diluted with added $300 \mu \mathrm{l}$ distilled water, vortexed hardly. The tube was kept into $-20^{\circ} \mathrm{C}$ in deep freezer for 10 minutes, then thawed and vortxed, three times successively. All the samples were centrifuged at $300 \mathrm{rpm}$ for 1 minute. A volume of $200 \mu \mathrm{l}$ of supernatant was aspirated to be used for DNA extraction [22-30].

\section{DNA extraction from tissues and cooked meat}

For extraction of DNA used the different organs of slaughtered gazelle and cooked meat. Commercial kit (QIAamp blood kit- QIAGEN Inc Chatsworth, CA, USA) was used according to the manufacturer's instructions. Briefly, $200 \mu \mathrm{l}$ from the Lysing buffer (L.A) were put in sterile epindorf tube, then $200 \mu$ of tissue lyses buffer were added, then, $200 \mu \mathrm{l}$ from the supernatant sample were added, vortexed the tubes then incubated in water bath at $70^{\circ} \mathrm{C}$ for 10 minutes. A volume of 200 $\mu \mathrm{l}$ absolute alcohol were added, vortexed and incubated in water bath at $70^{\circ} \mathrm{C}$ for 2 minutes. The contents were transferred from the epindorf tubes and put to QIA spin column. Spinning was performed at 8000 rplm for 2 minutes and the deposit was discarded. Washing was carried out with $500 \mu \mathrm{l}$ buffer one, vortexed and centrifuged at $8000 \mathrm{rpm}$ for 2 minutes. The QIAamp column was changed and washed with 500 $\mu \mathrm{l}$ buffer two, vortexed and centrifuged at $12000 \mathrm{rpm}$ for 3 minutes. The deposit was discarded and put the QIAamp column in epindorf tube and $200 \mu \mathrm{l}$ from elution buffer were added and left for 1 minute. Centrifugation was carried out at $8000 \mathrm{rpm}$ for 2 minutes, then, the column was discarded and the epindorf tube was kept at freezing degree.

\section{Phylogeny and sequencing}

The PCR product of 17 blood samples from Gazella dorcas sent to Macrogen Company for sequencing using forward primer (GZ1) and reverse primer (GZ2) of mitochondrial cytochrome- b gene. Used the sequences for phylogenetic analysis of Gazella dorcas in Sudan compared with other Gazella dorcas in GenBank in (Sudan, Saudi Arabia, King Khalid Wildlife in Saudi Arabia, Tunisia, Algeria, Chad, captive gazelle in Alwabra Wildlife Preservation in Qatar, Mali and Israel). For phylogeny used CLC DNA workbench and Mega 5 softwares. In this study the isolated species from Sudan were as follows: (1R, 2R, Q3, 4R, 5R, 6R, 7R, 8R, 9R, 10R, Q11, 12R, Q13, Q14, Q15, $\mathrm{Q} 1$ and Q2) by forward primer (GZ1). The same samples read by using reverse primer (GZ2) for the same species $(1,2, \mathrm{Q} 3,4,5,6,7,8,9,10$, Q11, Q12, Q13, Q14, Q15, Q1 and Q2).

\section{Results}

\section{Sequencing and phylogeny of Gazella dorcas}

Table 1 shows the comparison between Gazella dorcas isolated from Sudan with reference from GenBank. Figure 1 shows the sequence of mitochondrial cytochrome- b gene of Gazella dorcas in Sudan. Figure 2 shows JN410247.1: Accession number of Gazella dorcas isolated from east of the Nile- Sudan from the GenBank, (GZ) Sudan: Isolated Gazella dorcas from different places in Sudan in this study. The PCR product of 17 blood samples from Gazella dorcas sent to Macrogen Company for sequencing using forward primer (GZ1) and reverse primer (GZ2) of mitochondrial cytochrome- $b$ gene. Used the sequences for phylogenetic analysis of Gazella dorcas in Sudan compared with other Gazella dorcas in GenBank in (Sudan, Saudi Arabia, King Khalid Wildlife, Tunisia, Algeria, Chad, captive gazelle in Alwabra Wildlife

$$
\begin{aligned}
& \text { TCCCACTCCTAGTTCTCACACTCCTAGTTTCTCACACTCCTAGTTCTCACACTCCTAGTTCTCACACTCCTAGTTCTCACACTCCTAGTTCTCAC } \\
& \text { ACTCCTAGTTCTCACACTCCTAGTTCTCACACTCCTAGTTCTCACACTCCTAGTTCTCACACTCCTAGTTCTCACACTCCTAGTTTTCACACACC } \\
& \text { TAGTAGTTCTCACACTCCTAGTTCTCACACTCCTAGTTCTCACACTCCTAGTTCTATTCTCACCAGACCTACTCGGAGACCCAGACAACTATAC } \\
& \text { ACCAGCAAATCCACTCAACACACCCCCACACATCAAACCTGAATGATACTTCTTATTCGCATATGCAATTCTCCGATCAATTCCCAATAAACTA } \\
& \text { GGAGGAGTCCTAGCCTTAGTCCTATCAATTCTAATCTTAATCCTTATACCCCTACTTCATACATCTAAACAACGAAGCATGATATTTCGGCCAAT } \\
& \text { CAGCCAATGCCTATTCTGAATTCTAGTAGCAGACCTGCTAACACTTACATGAATCGGAGGACAACCAGTCGAACACCCATACATTATTATCGG } \\
& \text { ACAACTAGCATCAATTATATATTTCCTACTCATTCTAGTACTGATACCAGCAGCCAGTACCATTGAAAATAGTCTCGGTGTGCCGTGGGACAAC } \\
& \text { GAGGAGTGTGAGAACTAGGAGTGTGAGAACTAGGAGTGTGAGAACTAGGAGTGTGAGAACTAGGAGTGTGAGAACTAGGAGTGTGAGAACT } \\
& \text { AGGAGTGTGAGAACTAGGAGTGTGAGAACTAGGAGTGTGAGAACTAGGAGTGTGAGAACTAGGAGTGTGAGAACTAGGAGTGTGAGAACTA } \\
& \text { GGAGTGTGAGAACTAGGAGTGTGAGAACTAGGAGTGTGAGAACTAGGAGTGTGAGAACTAGGAGTGTGAGAACTAGGAGTGTGAGAACTAG } \\
& \text { GAGTGTGAGAACTAGGAGTGTGAGAACTAGGAGTGTGAGAACTAGGAGTGTGA }
\end{aligned}
$$

Figure 1: The sequence of mitochondrial cytochrome- b gene of Gazella dorcas in Sudan. 


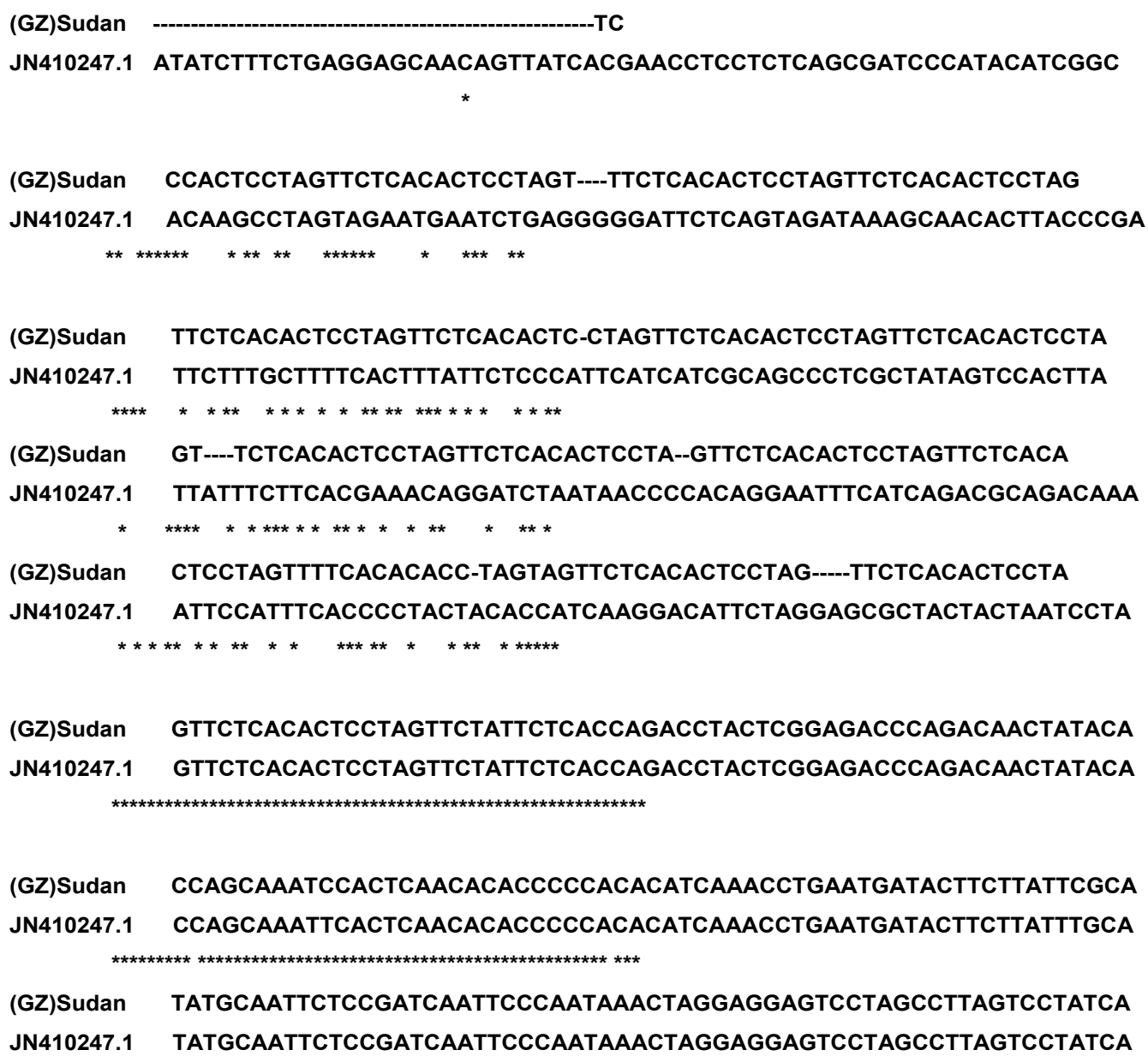

Figure 2: JN410247.1: Accession number of Gazella dorcas isolated from east of the Nile- Sudan from the GenBank. (GZ) Sudan: Isolated Gazella dorcas from different places in Sudan in this study. 


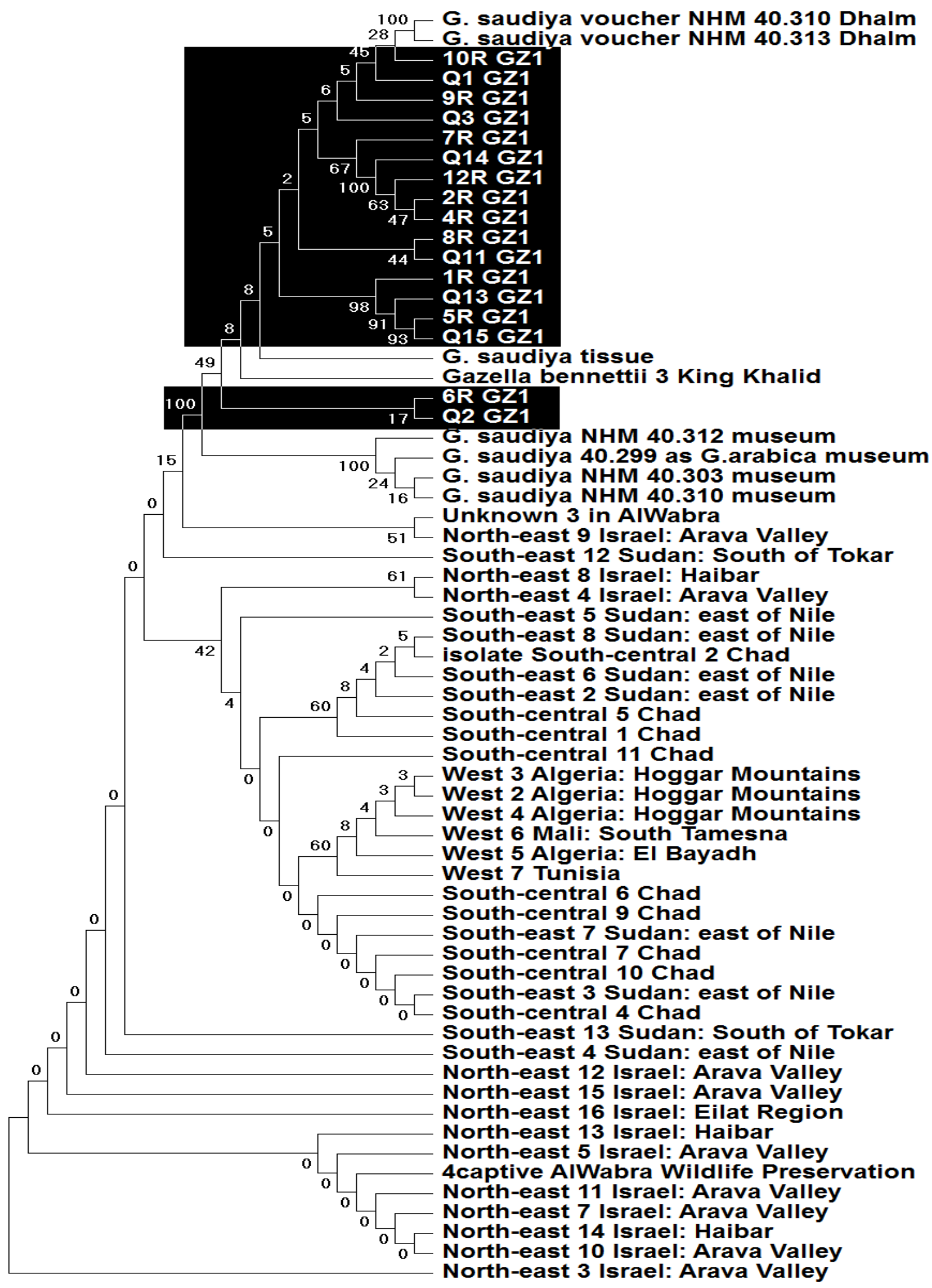

Figure 3: Phylogenetic tree for Gazella dorcas using GZ1. 


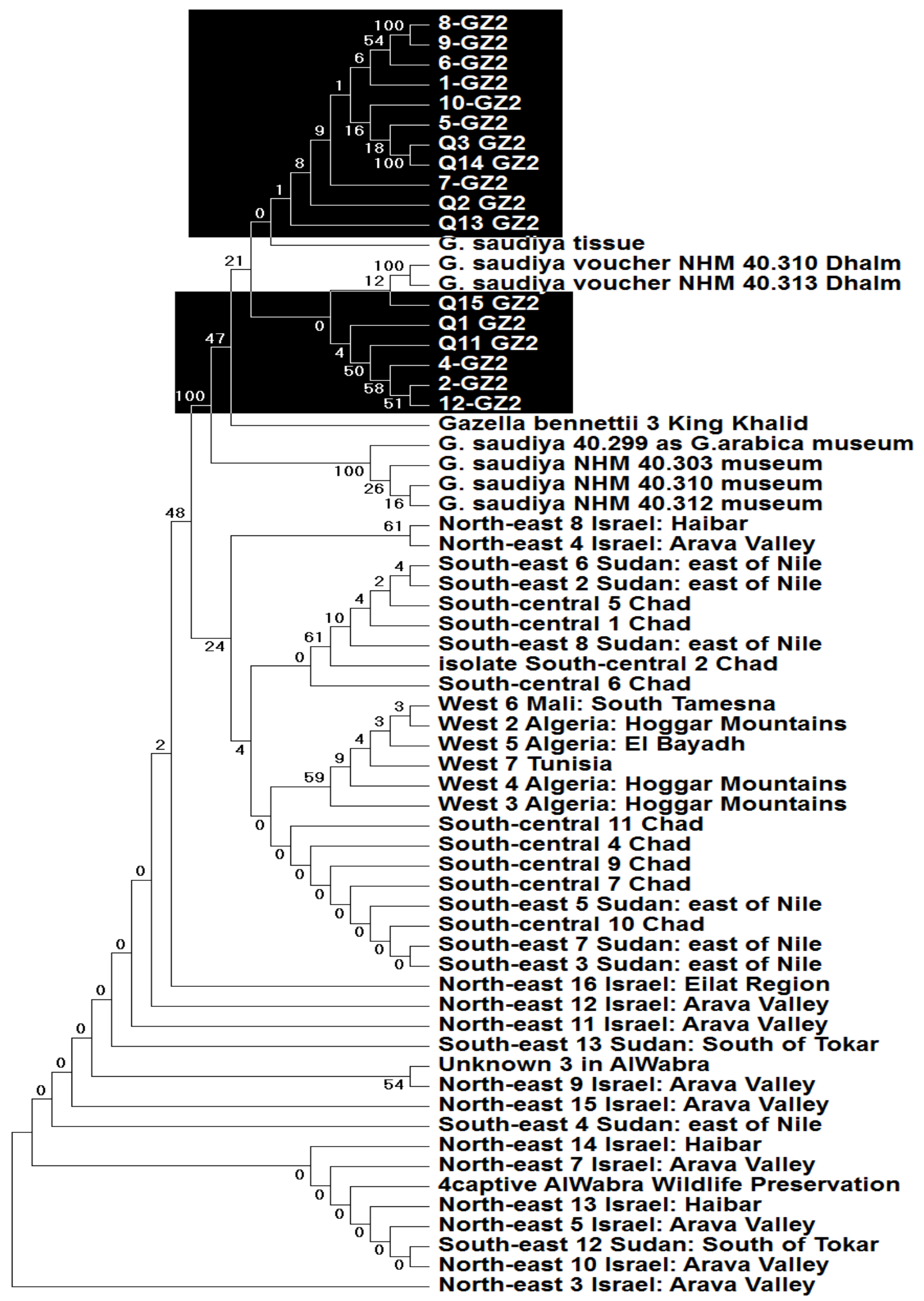

Figure 4: Phylogenetic tree for Gazella dorcas using GZ2. 
Citation: Salih RRM, Imad-Eldain ETA, Abd-Elrahim EK (2018) Phylogenetic Relationships of Sudanese Gazella dorcas Based on Mitochondrial Cytochrome-B Gene Sequences. J Mol Genet Med 12: 379 doi:10.4172/1747-0862.1000379

Page 6 of 7

\begin{tabular}{|c|c|c|c|c|c|c|c|c|c|c|c|c|c|c|c|c|c|c|c|c|c|c|c|c|}
\hline \multirow{2}{*}{\begin{tabular}{|c|}
$\begin{array}{c}\text { Name of } \\
\text { Sequence }\end{array}$ \\
$1 R-G Z 1$ \\
\end{tabular}} & \multicolumn{24}{|c|}{ The number of different ion between query and subject } \\
\hline & $\begin{array}{l}76 \\
T^{*} \\
A\end{array}$ & \begin{tabular}{|c|}
79 \\
$\mathrm{~T}^{*}$ \\
$\mathrm{~A}$ \\
\end{tabular} & $\begin{array}{l}82 \\
-^{-} \\
\mathrm{C}\end{array}$ & $\begin{array}{c}86 \\
-^{*} \\
T\end{array}$ & $\begin{array}{l}92 \\
C^{*} \\
- \\
\end{array}$ & $\begin{array}{c}101 \\
-^{*} \\
\mathrm{~A}\end{array}$ & $\begin{array}{c}145 \\
\mathrm{G}^{*} \\
\mathrm{~T}\end{array}$ & $\begin{array}{c}381 \\
\mathrm{G}^{*} \\
\mathrm{~A}\end{array}$ & & & & & & & & & & & & & & & & \\
\hline 2R- GZ1 & $\begin{array}{l}90 \\
\mathrm{C}^{*} \\
\mathrm{G}\end{array}$ & $\begin{array}{l}93 \\
\mathrm{~T}^{*} \\
\mathrm{~A}\end{array}$ & $\begin{array}{l}99 \\
\mathrm{~T}^{*} \\
\mathrm{~A}\end{array}$ & $\begin{array}{c}108 \\
\mathrm{~T}^{*} \\
\mathrm{~A}\end{array}$ & $\begin{array}{c}111 \\
\mathrm{~T}^{*} \\
\mathrm{~A}\end{array}$ & $\begin{array}{c}382 \\
\mathrm{G}^{*} \\
\mathrm{~A}\end{array}$ & & & & & & & & & & & & & & & & & & \\
\hline 3Q- GZ1 & $\begin{array}{l}73 \\
\mathrm{~T}^{*} \\
\mathrm{~A}\end{array}$ & $\begin{array}{l}76 \\
T^{*} \\
A\end{array}$ & $\begin{array}{c}88 \\
C^{*} \\
T\end{array}$ & $\begin{array}{l}97 \\
\mathrm{~T}^{*} \\
\mathrm{~A}\end{array}$ & $\begin{array}{c}109 \\
\mathrm{~T}^{*} \\
\mathrm{~A}\end{array}$ & $\begin{array}{c}380 \\
\mathrm{G}^{*} \\
\mathrm{~A}\end{array}$ & & & & & & & & & & & & & & & & & & \\
\hline 4R- GZ1 & $\begin{array}{c}86 \\
A^{*} \\
T\end{array}$ & $\begin{array}{c}90 \\
\mathrm{C}^{*} \\
\mathrm{~T}\end{array}$ & $\begin{array}{l}93 \\
\mathrm{~T}^{*} \\
\mathrm{~A}\end{array}$ & $\begin{array}{l}99 \\
\mathrm{~T}^{*} \\
\mathrm{~A}\end{array}$ & $\begin{array}{c}111 \\
\mathrm{~T}^{*} \\
\mathrm{~A}\end{array}$ & $\begin{array}{c}382 \\
\mathrm{G}^{*} \\
\mathrm{~A}\end{array}$ & & & & & & & & & & & & & & & & & & \\
\hline 5R- GZ1 & $\begin{array}{l}74 \\
\mathrm{~T}^{\star} \\
\mathrm{A}\end{array}$ & $\begin{array}{c}89 \\
\mathrm{C}^{*} \\
\mathrm{~T}\end{array}$ & & & & & & & & & & & & & & & & & & & & & & \\
\hline 6R- GZ1 & $\begin{array}{c}103 \\
\mathrm{~A}^{*} \\
\mathrm{~T}\end{array}$ & $\begin{array}{c}121 \\
\mathrm{C}^{*} \\
\mathrm{~A}\end{array}$ & $\begin{array}{c}125 \\
\mathrm{~T}^{*} \\
\mathrm{~A}\end{array}$ & $\begin{array}{c}350 \\
\mathrm{C}^{*} \\
\mathrm{~T}\end{array}$ & $\begin{array}{c}356 \\
\mathrm{G}^{*} \\
\mathrm{~A}\end{array}$ & $\begin{array}{c}384 \\
\mathrm{G}^{*} \\
\mathrm{~A}\end{array}$ & & & & & & & & & & & & & & & & & & \\
\hline 7R- GZ1 & $\begin{array}{l}75 \\
\mathrm{~T}^{*} \\
\mathrm{~A}\end{array}$ & $\begin{array}{l}81 \\
-^{*} \\
\mathrm{C}\end{array}$ & $\begin{array}{c}83 \\
\mathrm{G}^{*} \\
\mathrm{~T}\end{array}$ & $\begin{array}{c}86 \\
\mathrm{G}^{*} \\
\mathrm{~T}\end{array}$ & $\begin{array}{l}91 \\
\mathrm{~A}^{*} \\
\mathrm{G}\end{array}$ & $\begin{array}{c}93 \\
\mathrm{G}^{*} \\
\mathrm{~A}\end{array}$ & $\begin{array}{l}98 \\
-^{*} \\
C\end{array}$ & $\begin{array}{l}99 \\
\mathrm{G}^{*} \\
\mathrm{~A}\end{array}$ & $\begin{array}{c}108 \\
G^{*} \\
A\end{array}$ & $\begin{array}{c}109 \\
A^{*} \\
T\end{array}$ & \begin{tabular}{c|}
110 \\
$-^{*}$ \\
$C$
\end{tabular} & $\begin{array}{c}126 \\
\mathrm{~T}^{*} \\
\mathrm{~A}\end{array}$ & $\begin{array}{c}143 \\
\mathrm{G}^{*} \\
\mathrm{~T}\end{array}$ & $\begin{array}{c}144 \\
\mathrm{~T}^{*} \\
\mathrm{C}\end{array}$ & $\begin{array}{c}145 \\
\mathrm{G}^{*} \\
\mathrm{C}\end{array}$ & $\begin{array}{c}161 \\
\mathrm{G}^{*} \\
\mathrm{~T}\end{array}$ & $\begin{array}{c}176 \\
\mathrm{G}^{*} \\
\mathrm{~T}\end{array}$ & $\begin{array}{c}194 \\
-^{*} \\
\text { A }\end{array}$ & $\begin{array}{c}195 \\
C^{*} \\
A\end{array}$ & $\begin{array}{c}241 \\
A^{*} \\
T\end{array}$ & $\begin{array}{c}244 \\
\mathrm{G}^{*} \\
\mathrm{~T}\end{array}$ & $\begin{array}{c}246 \\
C^{*} \\
G\end{array}$ & $\begin{array}{c}248 \\
\mathrm{~T}^{*} \\
\mathrm{~A}\end{array}$ & $\begin{array}{c}272 \\
\mathrm{G}^{*} \\
\mathrm{C}\end{array}$ \\
\hline 8R- GZ1 & $\begin{array}{c}294 \\
\mathrm{~T}^{*} \\
\mathrm{~A}\end{array}$ & $\begin{array}{c}377 \\
A^{*} \\
G\end{array}$ & & & & & & & & & & & & & & & & & & & & & & \\
\hline 9R- GZ1 & $\begin{array}{c}262 \\
\mathrm{~T}^{*} \\
\mathrm{~A}\end{array}$ & $\begin{array}{c}266 \\
\mathrm{~T}^{*} \\
\mathrm{G}\end{array}$ & $\begin{array}{c}271 \\
-^{*} \\
G\end{array}$ & $\begin{array}{c}275 \\
A^{*} \\
-\end{array}$ & $\begin{array}{c}276 \\
A^{*} \\
G\end{array}$ & $\begin{array}{c}278 \\
A^{*} \\
C\end{array}$ & $\begin{array}{c}281 \\
T^{*} \\
-\end{array}$ & & & & & & & & & & & & & & & & & \\
\hline 10R- GZ1 & $\begin{array}{l}65 \\
\mathrm{~T}^{*} \\
\mathrm{~A}\end{array}$ & $\begin{array}{l}89 \\
-* \\
A\end{array}$ & & & & & & & & & & & & & & & & & & & & & & \\
\hline 11Q- GZ1 & $\begin{array}{l}76 \\
\mathrm{~T}^{*} \\
\mathrm{~A}\end{array}$ & $\begin{array}{c}79 \\
\mathrm{~T}^{*} \\
\mathrm{~A}\end{array}$ & $\begin{array}{l}82 \\
\mathrm{~T}^{*} \\
\mathrm{C}\end{array}$ & $\begin{array}{l}87 \\
A^{*} \\
T\end{array}$ & $\begin{array}{l}91 \\
\mathrm{C}^{*} \\
\mathrm{~T}\end{array}$ & $\begin{array}{l}92 \\
C^{*} \\
G\end{array}$ & $\begin{array}{c}94 \\
\mathrm{~T}^{*} \\
\mathrm{~A}\end{array}$ & $\begin{array}{c}100 \\
\mathrm{~T}^{*} \\
\mathrm{~A}\end{array}$ & $\begin{array}{c}106 \\
\mathrm{~T}^{*} \\
\mathrm{C}\end{array}$ & $\begin{array}{c}111 \\
\mathrm{G}^{*} \\
\mathrm{C}\end{array}$ & $\begin{array}{c}112 \\
\mathrm{~T}^{*} \\
\mathrm{~A}\end{array}$ & $\begin{array}{c}113 \\
T^{*} \\
A\end{array}$ & $\begin{array}{c}382 \\
G^{*} \\
A\end{array}$ & $\begin{array}{r}384 \\
-* \\
\mathrm{~A}\end{array}$ & & & & & & & & & & \\
\hline 12R- GZ1 & $\begin{array}{c}75 \\
T^{*} \\
A\end{array}$ & $\begin{array}{l}90 \\
\mathrm{C}^{*} \\
\mathrm{~T}\end{array}$ & $\begin{array}{c}99 \\
\mathrm{~T}^{*} \\
\mathrm{~A}\end{array}$ & & & & & & & & & & & & & & & & & & & & & \\
\hline 13Q- GZ1 & $\begin{array}{c}74 \\
\mathrm{~T}^{\star} \\
\mathrm{A}\end{array}$ & $\begin{array}{l}77 \\
\mathrm{~T}^{*} \\
\mathrm{~A}\end{array}$ & $\begin{array}{c}85 \\
\mathrm{~A}^{*} \\
\mathrm{~T}\end{array}$ & $\begin{array}{l}89 \\
C^{*} \\
T\end{array}$ & $\begin{array}{l}90 \\
\mathrm{C}^{*} \\
\mathrm{G}\end{array}$ & $\begin{array}{l}92 \\
\mathrm{~T}^{*} \\
\mathrm{~A}\end{array}$ & $\begin{array}{l}98 \\
\mathrm{~T}^{*} \\
\mathrm{~A}\end{array}$ & $\begin{array}{c}110 \\
\mathrm{~T}^{*} \\
\mathrm{~A}\end{array}$ & $\begin{array}{c}380 \\
\mathrm{G}^{*} \\
\mathrm{~A}\end{array}$ & $\begin{array}{c}382 \\
-^{*} \\
A\end{array}$ & & & & & & & & & & & & & & \\
\hline 14Q- GZ1 & $\begin{array}{c}75 \\
T^{*} \\
A\end{array}$ & $\begin{array}{l}90 \\
\mathrm{C}^{*} \\
\mathrm{~T}\end{array}$ & $\begin{array}{l}91 \\
\mathrm{C}^{*} \\
\mathrm{G}\end{array}$ & $\begin{array}{c}99 \\
\mathrm{~T}^{*} \\
\mathrm{~A}\end{array}$ & $\begin{array}{c}111 \\
\mathrm{~T}^{*} \\
\mathrm{~A}\end{array}$ & $\begin{array}{c}174 \\
\mathrm{G}^{*} \\
\mathrm{~A}\end{array}$ & & & & & & & & & & & & & & & & & & \\
\hline 15Q- GZ1 & $\begin{array}{c}74 \\
T^{*} \\
A\end{array}$ & $\begin{array}{l}77 \\
\mathrm{~T}^{*} \\
\mathrm{~A}\end{array}$ & $\begin{array}{l}80 \\
\mathrm{~T}^{*} \\
\mathrm{C}\end{array}$ & $\begin{array}{l}85 \\
A^{*} \\
T\end{array}$ & $\begin{array}{l}90 \\
\mathrm{C}^{*} \\
\mathrm{G}\end{array}$ & $\begin{array}{l}92 \\
\mathrm{~T}^{*} \\
\mathrm{~A}\end{array}$ & $\begin{array}{l}96 \\
T^{*} \\
G\end{array}$ & $\begin{array}{l}98 \\
\mathrm{~T}^{*} \\
\mathrm{~A}\end{array}$ & $\begin{array}{c}110 \\
\mathrm{~T}^{*} \\
\mathrm{~A}\end{array}$ & $\begin{array}{c}380 \\
\mathrm{G}^{*} \\
\mathrm{~A}\end{array}$ & $\begin{array}{c}382 \\
-^{*} \\
A\end{array}$ & & & & & & & & & & & & & \\
\hline 1Q- GZ1 & $\begin{array}{c}234 \\
\mathrm{~T}^{*} \\
\mathrm{G}\end{array}$ & $\begin{array}{c}265 \\
\mathrm{~T}^{*} \\
\mathrm{~A}\end{array}$ & $\begin{array}{c}304 \\
\mathrm{~T}^{*} \\
\mathrm{C}\end{array}$ & $\begin{array}{c}329 \\
C^{*} \\
T\end{array}$ & $\begin{array}{c}363 \\
\mathrm{G}^{*} \\
\mathrm{~A}\end{array}$ & & & & & & & & & & & & & & & & & & & \\
\hline 2Q- GZ1 & $\begin{array}{c}221 \\
\mathrm{~T}^{*} \\
\mathrm{G}\end{array}$ & $\begin{array}{c}224 \\
C^{*} \\
A^{*}\end{array}$ & $\begin{array}{c}235 \\
\mathrm{G}^{*} \\
\mathrm{~T}\end{array}$ & $\begin{array}{c}259 \\
C^{*} \\
A\end{array}$ & $\begin{array}{c}260 \\
\mathrm{~T}^{*} \\
\mathrm{C}\end{array}$ & $\begin{array}{c}268 \\
\mathrm{G}^{*} \\
\mathrm{~T}\end{array}$ & $\begin{array}{c}276 \\
\mathrm{G}^{*} \\
\mathrm{~A}\end{array}$ & $\begin{array}{c}279 \\
\mathrm{~T}^{*} \\
\mathrm{~A}\end{array}$ & $\begin{array}{c}298 \\
\mathrm{G}^{*} \\
\mathrm{~T}\end{array}$ & $\begin{array}{c}332 \\
\mathrm{~T}^{*} \\
\mathrm{~A}\end{array}$ & & & & & & & & & & & & & & \\
\hline
\end{tabular}

Table 1: Comparison between Gazella dorcas isolated from Sudan with reference from GenBank.

Preservation, Mali and Israel). For phylogeny used Mega 4 software. Figure 3 shows the tree of Gazella dorcas compared with other species from GenBank. In this study the isolated species from Sudan were as follows: (1R, 2R, Q3, 4R, 5R, 6R, 7R, 8R, 9R, 10R, Q11, 12R, Q13, Q14, $\mathrm{Q} 15, \mathrm{Q} 1$ and Q2) by forward primer. Figure 4 shows the same samples read by using reverse primer GZ2 for the same species $(1,2, \mathrm{Q} 3,4,5$, 6, 7, 8, 9, 10, Q11, Q12, Q13, Q14, Q15, Q1 and Q2). All species were much closer to Gazella saudiya more than other species isolated from other countries.

\section{Discussion}

Lack of detailed information about phylogenetic relationships among and within threatened groups of animals can hamper conservation efforts [31-33]. For instance, unrecognized differentiation within a putative species can lead to admixture of independent evolutionary entities in captivity. In this context, conservation genetic approaches are valuable tools for captive breeding and in situ conservation programs as morphologically indiscernible (cryptic) animal species appear to exist throughout taxonomic groups and biogeographic regions $[25,27,30]$.

In this study we used PCR on the Gzaella dorcas in Sudan using 421 bp of mitochondrial DNA (mtDNA) cytochrome- b gene derived from blood and tissues samples collected from the Gazella dorcas. The 
Citation: Salih RRM, Imad-Eldain ETA, Abd-Elrahim EK (2018) Phylogenetic Relationships of Sudanese Gazella dorcas Based on Mitochondrial Cytochrome-B Gene Sequences. J Mol Genet Med 12: 379 doi:10.4172/1747-0862.1000379

Page 7 of 7

polymerase chain reaction analysis of blood samples collected from living gazelles in Bahry and East of Nile in Sudan.

We conduct another experiment it was sequencing and phylogeny of Dorcas gazelles which were examined in this study compared with other species of Gazella dorcas, Gazella saudiy and Gazella benetti which were found in GenBank. The examined gazelles were closer to Gazella saudiya more than other species and this in agreement with findings of $[23,26]$. May be the Gazella dorcas in Sudan was transported to Saudi Arabia or from the last one to Sudan.

\section{Conclusion and Recommendation}

In conclusion the phylogeny of Gazella dorcas will be apply by use complete mitochondrial cytochrome- $b$ gene alternative from partial fragments of the gene which were used in this study.

There is, therefore, need to conduct research that can determine the practicability of LAMP method being applied for diagnosis in the field, such as conducting LAMP experiments at field ambient temperatures, and determining simple DNA template preparations which could also be easily applied in the field. Ecological, biological, and genetic knowledge of wildlife has traditionally been covered in the disciplines of wildlife ecology, physiology and conservation genetics and it is this research that forms the foundation for the interpretation of genetic data for forensic applications.

We argue that for forensic science to advance in the field of wildlife biology, cross-disciplinary collaborations with ecologists, biologists and conservation geneticists are essential. Phylogenetic, phylogeographic and population genetic studies are required for species, population and individual identification of wildlife, respectively. The objectives of conservation research are often complimentary with forensic outcomes. For example, phylogenetics can be used to delineate species boundaries and this is important for the enforcement of wildlife legislation, which recognizes and protects groups that are classed as 'species' or 'subspecies'.

\section{Acknowledgement}

Thanks for Imadeldeen. E.E. Aradaib for prepared his Lab for help and fund to make the experiment completely.

\section{References}

1. Alados CL (1987) A cladistic approach to the taxonomy of the Dorcas gazelles. Israel J Zoology 34: 33-49.

2. Baharav D (1980) Habitat utilization of the Dorcas gazelle in a desert saline area. J Arid Environ 3: 161-167.

3. Baharav D (1982) Desert habitat partioning by the Dorcas gazelle. J Arid Environ 5: 323-335.

4. Baharav D (1983) Reproductive strategies in female mountain and Dorcas Gazelles (Gazella gazella gazella and Gazella dorcas). J Zoology 200: 445-453.

5. Boore JL (1999) Animal mitochondrial genomes. Nucleic Acids Res 27: 1767-1780.

6. Carlisle DB, Ghobrial LI (1968) Food and water requirements of dorcas gazelle in the Sudan. Mammalia 32: 570-576

7. Elson JL, Lightowlers RN (2006) Mitochondrial DNA clonality in the dock: Can surveillance swing the case?. Trends Genet 22: 603-607.

8. Ghobrial LI (1970) Water relations of the desert antelope Gazella dorcas dorcas. Physiol Zoology 43: 249-256.

9. Ghobrial LI (1974) Water relations and requirement of the Dorcas gazelle in the Sudan. Mammalia 38: 88-101.
10. Ghobrial LI, Cloudsley TJ (1976) Daily cycle of activity of Dorcas gazelle in Sudan. J Interdiscipl Cycle Res 7: 47-50.

11. Groves CP (1969) On the smaller gazelles of the genus Gazella de Blainville. Zeitschrift für Säugetierkunde 37: 38-60.

12. Groves CP (1985a) Pelzeln's gazelle and its relatives. Chinkara 1: 20-25.

13. Groves CP (1985b) An introduction to the gazelles. Chinkara 1: 4-16.

14. Groves CP (1988) A catalogue of the genus Gazella. In: Conservation and biology of desert antelopes C. Helm Publishers Ltd, London.

15. Groves CP (1981) Notes on gazelles. The Dorcas gazelles of north Africa. Anali Museo Civicio di Storia Naturale di Genova 83: 455-471.

16. Hebert PD, Stoeckle MY, Zemlak TS, Francis CM (2004) Identification of birds through DNA barcodes. PLOS Biol 2: 312.

17. Hsieh HM, Chiang HL, Tsai LC, Lai SY, Huang NE, et al. (2001) Cytochrome $\mathrm{b}$ gene for species identification of the conservation animals. Forensic Sci Int 122: 7-18.

\section{8. http://www.iucnredlist.org.}

19. Johannes AL, Jacob BB, Frederik WJ (2001) On the origin of meat: DNA techniques for species identification in meat products. Veterinary Sci Tomorrow 2: 1.

20. Kartavtsev YP, Lee JS (2006) Analysis of nucleotide diversity at genes cytochrome band cytochrome oxidase 1 on population, species, and genera levels. Russ J Genet 42: 341-362.

21. Lafontaine RM, Beudels-Jamar RC, Devillers P, Wacher T (2006) Gazella dorcas. In: Status and Perspectives. Report on the conservation status of the six Sahelo-Saharan Antelopes. Bonn, UNEP/CMS Secretariat, Germany.

22. Lerp H, Wronski T, Pfenniger M, Plath M (2011) Aphylogeoraphic framework for the conservation of Saharan and Arabian Dorcas gazelles (Artiodactyla: Bovidae). Org Divers Evol 11: 317- 329.

23. Mallon DP, Kingswood SC (2001) Antelopes. Part 4: North Africa, the Middle East and Asia. Global Survey Action Plans. Gland, Switzerland and Cambridge IUCN.

24. Pfenninger M, Schwenk K (2007) Cryptic animal species are homogeneously distributed among taxa and biogeographical regions. BMC Evolut Biol 7: 121.

25. Robert LH, William M, Benito F, Osborn BM, Tim W, et al. (2001) Phylogenetic reanalysis of the Saudi gazelle and its implications for conservation. Conserv Biol 15: 1123-1133.

26. Rueness EK, Asmyhr MG, Sillero-Zubiri C, Macdonald DW, Bekele A, et al (2011) The Cryptic African Wolf: Canis aureus lupaster is not a golden jackal and is not endemic to Egypt. Plos One 6: 1-2.

27. Smith T (1998) Sahelo-Saharan antelopes draft status report. UNEP Convention on Migratory Species (CMS). Brussels: Institut Royal des Sciences Naturelles de Belgique.

28. Smith T (1999) Report on the status and perspectives of a species: Gazella dorcas. In: Report on the conservation status of the six Sahelo-Saharan Antelopes. Bonn, Germany: UNEP/CMS Secretariat.

29. Trontelj P, Fišer C (2009) Cryptic species diversity should not be trivialised System Biodiv 7: 1-3.

30. UNEP/CMC (1998) Proceedings of the seminar on the conservation and restoration of sahelo-saharan antelopes. Brussels: Convention on Migratory Species and Institut Royal des Science Naturelles de Belgique, Belgium.

31. Vogler AP, Desalle A (1994) Diagnosing units of conservation management Conserv Biol 8: 354-363.

32. Wacher T, Newby JE, Monfort S, Tubiana J, Moksia D, et al. (2004) SaheloSaharan interest group antelope update Chad 2001 and Niger 2002. In IUCN Antelope Survey Update. Gland, Switzerland: IUCN 9: 52-59.

33. Yom-Tov Y, Mendelssohn H, Groves CP (1995) Gazella dorcas. Mammalian Species 491: 1- 6. 